Reviews

1999. Natural Capitalism: Creating the Next Industrial Revolution. Boston: Little, Brown and Company. Mol, Arthur P.J. and Gert Spaargaren.

2000. Ecological Modernisation Theory in Debate: A Review. Environmental Politics 9(1): 17-49.

Ruggie, John Gerard.

1995. At Home Abroad, Abroad At Home: International Liberalisation and Domestic Stability in the New

World Economy. Millennium 24(3): 507-526

Vogel, David.

1995. Trading Up: Consumer and Environmental Regulation in a Global Economy. Cambridge, MA: Harvard University Press.

\title{
Brave New Seeds: The Threat of GM Crops to Farmers, by Robert Ali Brac de la Perriere, and Franck Seuret. London: Zed Books (2000), 160 pp.
}

\section{Reviewed by Glenn Davis Stone, Department of Anthropology, Washington University, St. Louis MO 63130.}

This little book, with a bold title and backed by an aggressive marketing campaign by Zed Books, is the latest entry into the turbulent debate on genetically modified (GM) crops. The preface introduces it as one of a series of "short, accessible think pieces" on global issues. That's true in the sense that the book tells what some people think about GM crops. It's not true in the sense of "thinking through" an issue, or even offering new thoughts.

The authors are an "international consultant" and a journalist, and the people whose thoughts they report on were 39 conferees who met in India in December of 1998. Most are from India or western Europe, with a few Africans, North Americans, and Latin Americans. It is unclear how the group was selected, but it was not on the basis of contributions to the scientific or social science literature on GM crops. Their meeting is claimed to have been a "multicultural debate" on GM agriculture (p. 3) but there is no sign of debate in the book; it's pure green polemic, beginning and ending with the conviction that GM agriculture "threatens to carry away all that remains of the fabulous vegetal heritage gathered down the ages" by farmers in India and elsewhere in the developing world (pp. 1-2).

The anti-GM arguments are presented in 7 chapters such as "Terminator, Out!" and "About Ethics: Tampering With the Foundations of Life." The claims will be familiar to most readers: GM crops are likely dangerous to human health and the environment, they threaten farmer independence (in fact, are part of the "programmed elimination of small farmers"), they will endanger southern countries' control over their agricultural germplasm, and they aren't needed anyway because hunger results from inequalities rather than shortages.

The book exemplifies the regrettably polarized character of the debate on GM crops. This has turned into a spin war that pushes both sides to devious positions (Stone 2000): corporate media touts a disingenuous malthusianism and inflated claims on the humanitarian benefits of their products, while green critics obstinately deny that GM crops have any promise whatsoever. A case in point from this book is the issue of apomixis -- the property of asexual reproduction, occurring naturally in some plants and apparently transferrable to new plants. While GM today is widely associated with "Terminator" technology which would remove farmer control over seed reproduction, the development of apomictic plants through genetic modification would allow increased farmer control. All hybrid seeds are "terminator" seeds in that heterosis (hybrid vigor) is lost in the second generation. But apomixis could lock the benefits of heterosis into a replantable pure line. Progress has been slow using conventional breeding techniques, and genetic modification promises to greatly expedite research. It is not yet known how this apomixis technology will affect farming in the south (Bicknell and Bicknell 1999), but clearly the potential is enormous. Remaining true to the polarized debate, Brave New Seeds claims apomixis to be no more than a means for seed companies to reduce production costs, while reducing plants' capacity to adapt to changes in the environment (p. 35). Another example: researchers in non-commercial labs have developed cassava resistant to the mosaic virus that ruins part of the African harvest each year; this is a vegetatively reproduced crop that could remain outside of corporate control. How these technologies are deployed, and how we are to weigh their risks and benefits, are crucial issues for agriculture in the south, certainly deserving of a more open-minded airing than they receive

$118 \quad$ Vol. 82001

Journal of Political Ecology 
Reviews

here.

However sympathetic one may be to the book's stance, the fact is that it is more diatribe than scholarship. In fact, there is only the feeblest of scholarly support offered for the barrage of accusations. Much of the book consists of verbatim opinions aired at the 1998 conference, often backed only by references to tracts from other anti-GM activists such as GRAIN, Greenpeace, Gaia Foundation, RAFI, or Vandana Shiva. Such activist tracts even serve as sources on empirical aspects of agriculture: e.g., RAFI is credited with the fact that $70 \%$ of GM seeds contain herbicide resistance [p. 13; this figure has been nudged up to $71 \%$ by p. 57]. Some points are supported by quotes from activists quoting other activists: the key point that hunger stems from poverty rather than shortages is referenced by a quote from Neil Ritchie of the Inst. of Agricultural and Trade Policy, quoting Peter Rossett of Food First (p. 62). There are pseudocitations (like to the unnamed "specialists [who] estimate that in developing countries about $80 \%$ of the seeds used come from farmers' fields") and many totally unsupported statements ("farmers in countries of the South... will be forced to buy genetically modified seeds instead of the 'traditional' seeds they have been using until now" (p. 11)). I happen to believe that some of the book's complaints about potential effects on developing world farming have some merit, but these issues are contentious and complex, and readers should be wary of such strong critiques with such weak documentation.

One concrete effect of the book's neglect of the relevant literature is that the "sustainable" agriculture that it champions throughout is contrasted to "intensive" agriculture. This is an unfortunate contrast, as some of the most widely-read books in the agrarian ecology literature deal precisely with how and why the most productive forms of sustainable indigenous agriculture are intensive (Netting 1993; Tiffen et al. 1994).

At only 145 smallish pages, Brave New Seeds can be read in a couple of hours, but in all candor I must report that to be a dubious use of time. For readers who want to explore the anti-GM activist literature, there is no shortage of material that is equally accessible, more current, better informed, and certainly better supported. For instance, on the deleterious effects of corporate agriculture on small farmers, see Magdoff et al. (2000) or Lappé and Bailey (1998); on biotechnology and intellectual property rights, see Kloppenburg (1988) or the numerous RAFI online publications (www.rafi.org); on environmental safety, see the numerous publications available from Union of Concerned Scientists (www.ucsusa.org); on the disingenuous malthusianism, see Lappé et al. (1998) or Ross (1998).

\section{References Cited:}

Kloppenburg, Jack Ralph Jr.

1988. First the Seed: The Political Economy of Plant Biotechnology, 1492-2000. Cambridge: Cambridge University Press.

Francis M. Lappé, Joseph Collins, and Peter Rosset.

1998. World Hunger: 12 Myths (2nd edition). New York: Grove Press.

Lappé Marc, and Britt Bailey.

1998. Against the Grain: Biotechnology and the Corporate Takeover of Your Food. Monroe, ME: Common Courage Press.

Magdoff, Fred, J. B. Foster, and F. H. Buttel.

2000. Hungry for Profit: The Agribusiness Threat to Farmers, Food, and the Environment. New York: Monthly Review Press.

Netting, Robert McC.

1993. Smallholders, Householders: Farm Families and the Ecology of Intensive, Sustainable Agriculture. Stanford: Stanford University Press.

Ross, Eric B

1998. The Malthus Factor: Population, Poverty, and Politics in Capitalist Development. London: Zed Books.

Stone, Glenn Davis.

2000. "Both Sides Now: Ecological and Political Fallacies on GM Crops." Paper presented at the Annual Meeting of the American Anthropological Association, SanFrancisco, November, 2000.

Tiffen, Mary, Michael Mortimore, and Francis Gichuki

1994. More people, less erosion: Environmental recovery in Kenya. Wiley, Chichester. 